\title{
Phytoremediation potential of some grasses on lead heavy metal in tailing planting media of former tin mining
}

\author{
NYAYU SITI KHODIJAH ${ }^{1, \vartheta}$, RUJITO AGUS SUWIGNYO ${ }^{2, v »}$, M. UMAR HARUN ${ }^{2}$, LUCY ROBIARTINI ${ }^{2}$ \\ ${ }^{1}$ Program of Agrotechnology, Universitas Bangka Belitung. UBB Campus of Balunijuk, Bangka District 33126, Bangka Belitung Province, Indonesia, \\ Tel.: +62-711-4260046, `email: nyayukhodijah@yahoo.co.id \\ ${ }^{2}$ Department of Agriculture, Faculty of Agriculture, Universitas Sriwijaya. J1.Palembang-Prabumulih Km.32, Indralaya, Ogan Ilir 30662, South Sumatra, \\ Indonesia. Tel.: +62-896-3874-9695, "vemail: rujito62@yahoo.co.id
}

Manuscript received: 12 December 2018. Revision accepted: 27 June 2019.

\begin{abstract}
Khodijah NS, Suwignyo RA, Harun MU, Robiartini L. 2019. Phytoremediation potential of some grasses on lead heavy metal in tailing planting media of former tin mining. Biodiversitas 20: 1973-1982. Agricultural production on tin tailings land must consider the safety of products from $\mathrm{Pb}$ metal contaminants. The presence of $\mathrm{Pb}$ metal can be overcome by using plants as phytoremediation. This study aimed to obtain information on the ability of phytoremediation of $\mathrm{Pb}$ by various types of grass and its interaction with the types of ameliorants in tin tailings media. Three species of grass were used, namely Pennisetum purpureum, Saccharum spontaneum, and Hymenachne acutigluma, and two types of ameliorant, namely lime and compost. The study was designed using a factorial treatment design laid out in a completely randomized design with two treatment factors, namely the type of grass and the type of ameliorant. Observations were done on growth, shoot $\mathrm{Pb}$ content and root $\mathrm{Pb}$ content. The ability of phytoremediation was assessed by using the approach of Bioconcentration factor (BCF) and Translocation Factor (TF) values. The highest phytoremediation ability was found in treatment of $\mathrm{H}$. acutigluma grass treated with lime ameliorant, followed by $S$. spontaneum treated with lime ameliorous and $S$. spontaneum treated with compost ameliorant. Based on BCF values, P. purpureum and H. acutigluma were categorized as accumulators, and $S$. spontaneum was classified as an excluder. Based on TF values, the three types of grass used were classified as phytostabilisation. The high ability of phytoremediation in $H$. acutigluma was caused by its high BCF values, while the high ability of phytoremediation on $\mathrm{S}$. spontaneum was caused by its low translocation factor value and high $\mathrm{Pb}$ absorption efficiency.
\end{abstract}

Keywords: Hymenachne acutigluma, lead, Pennisetum purpureum, phytoremediation, Saccharum spontaneum

\section{INTRODUCTION}

Lead $(\mathrm{Pb})$ is considered to be the most toxic environmental pollutant due to its toxicity and nonbiodegradability properties (Lou et al. 2013; Pinho and Ladeiro 2012). $\mathrm{Pb}$ in tin tailings land of the multiplier location reached $60.1 \mathrm{ppm}$ for land that has been abandoned for more than 40 years (Ferry et al. 2013), and in refined tin tailings land, it can reach $50.53 \mathrm{ppm}$ (Sari 2015). The absorption of metals from the soil depends on different factors such as soil $\mathrm{pH}$, plant growth stage, species, fertilizer and soil type (Kooner et al. 2014). Heavy metal toxicity and mobility depend not only on the total amount but also on the chemical fractionation on the ground (Yang et al. 2014). Therefore, it is necessary to choose a type of strategy for revegetation of post-mining land (Antwi et al. 2014) of which the vegetation can act as an absorber of $\mathrm{Pb}$ (Nascimento et al. 2014).

Phytoremediation method is the use of plants to extract, neutralize, accumulate and/or reduce contaminants from soil, water or air (Gerjardt et al. 2016) and is an effective and economical strategy for transporting heavy metals from the soil (Nascimento et al. 2014; Sarwar et al. 2017). Phytotoxicity is useful for reducing the risk associated with heavy metal contaminants through the use of hyperaccumulators (Pinho and Ladeiro 2012). The species used for revegetation and phytoremediation must have rapid growth potency and free of diseases and pests. They must be able to compete with less desirable species, capable to adapt to local soil and climatic conditions, and also able to grow in poor soils (Ranjan et al. 2015).

The selection of locally and perennial invasive grasses such as West Indian marsh grass or rumput kumpai (Hymenachne acutigluma (Steud.) Gilliland.), napier grass or rumput gajah (Pennisetum purpureum Schumach) and wild sugarcane or rumput gelagah (Saccharum spontaneum L.) is expected to be the choice of pioneer vegetation to restore the ecological functions of the soil after tin mining. Grasses are chosen because of their resistance to extreme post-mining conditions (Chuan et al. 2016), phytoremediation ability, and their subsequent economic value as feed that might be developed after mining. $H$. amplexicaulis was the favorite food of swamp buffalo (Windusari et al. 2014); in Australia, H. amplexicaulis is considered an invasive species (Grice et al. 2011) and is a perennial grass that could produce large amounts of biomass in the dry and rainy seasons (Magnano et al. 2018). $P$. purpureum is a plant species with high biomass production (Arunothai et al. 2014) as a potential bioenergy plant and can be a useful habitat for arthropods (Aparecida et al. 2014; Xavier et al. 2017). S. spontaneum is a grass species able to grow in heavy metal dumps (Nidaa et al. 2017) and it has the potential to restore fly ash deposits (Pandey et al. 2015; Mukharjee et al. 2017). 
Some soil amendments can be implemented to improve sandy soils, among others by adding organic matter, along with polymer fertilizers and selecting local species which are also adapted as pioneer vegetation (Oktavia et al. 2015). Pioneer plants can survive in the tailing environment with nutrient stress, high temperatures, and limited water, while other plants have not been able to live in such conditions. Efficiency of phytoextraction can be increased by crop cultivation management including soil management to improve metal tolerance, translocation and metal accumulation in plants (Sheoran et al. 2016). Amendments are used to increase biomass, including nitrogen, phosphorus and potassium (NPK) fertilizer, and sludge (Chirakkara et al. 2016: Zhang et al. 2016).

Bioconcentration factor (BCF) is used as an illustration of plant strength in accumulating $\mathrm{Pb}$ in tailings. The translocation factor (TF) shows the ability to transfer metals from the roots to the tops of plants. Bioconcentration factor (BCF) value and Translocation Factor (TF) values-based approaches can be used as indicators of the phytoremediation ability (Ghosh and Singh 2005; Sharma et al. 2010).

The aim of this study was to obtain information on the ability of phytoremediation of $\mathrm{Pb}$ by grasses due to the interaction of treatment of grass types and ameliorant types in tin tailings, and to study the factors involved based on growth, shoot and root $\mathrm{Pb}$ contents, absorption efficiency, Bioconcentration factor (BCF) and Translocation Factor (TF). This research is expected to contribute to obtaining effective, safe and economical ways of using tin tailings for agricultural activities.

\section{MATERIALS AND METHODS}

\section{Research site}

The present study used tailings media originating from the tin mining area located in Riding Panjang Village, Merawang Sub-district, Bangka District, Indonesia. The mining locations had not been operated in the last 20 years. Tailing sand was placed in pots and maintained in the experimental farm of the Faculty of Agriculture, Fisheries and Biology, University of Bangka Belitung, Indonesia. Planting of the grasses was started from May to October 2017. Analysis of Pb metal in tailing media and plant tissue $\mathrm{Pb}$ was done in the Soil Laboratory of University of Bangka Belitung, Indonesia and SEAMEO BIOTROP Bogor, Indonesia from August to December 2017.

\section{Research design}

The study was carried out using a factorial treatment design laid out in a completely randomized design. Two treatment factors were used, i.e., the first factor was the type of grass and the second factor was the addition of ameliorants to the tailing media. The type of grass used consisted of three species of grasses from the Poaceae grass family, namely: Hymenachne acutigluma, Pennisetum purpureum, and Saccharum spontaneum. The treatment factor of ameliorant addition consisted of two levels, i.e.,
Dolomite lime and compost. In total, there were six treatment combinations, each was six replications.

\section{Research materials}

The planting materials used were three types of grass: $P$. purpureum, $S$. spontaneum and. $H$. acutigluma. Ameliorants used were: agricultural dolomite lime $\left(\mathrm{CaCO}_{3}\right)$ and organic matter in the form of compost. NPK inorganic fertilizers (15: 15: 15) were used as additional nutrients in all treatment media.

\section{Preparation of planting media}

Tailings were placed in special pots with controlled aeration arrangements to maintain washing of nutrients from the growing media. For each type of grass, two types of ameliorants were added to the planting medium, the first type of ameliorant was lime. Lime was added to the tailings medium as much as $40 \mathrm{~g}$ of lime pot $^{-1}$ or equivalent to 6.8 tons $\mathrm{ha}^{-1}$, the time of lime administration was two weeks before planting and was continued after one week of after planting with the administration of $6 \mathrm{~g}$ of NPK fertilizer per pot, equivalent to $100 \mathrm{~kg} \mathrm{ha}^{-1}$. The second type of ameliorant was compost. Compost was added to the media as much as $0.9 \mathrm{~kg}$ of compost pot ${ }^{-1}$, equivalent to $15 \mathrm{t} \mathrm{ha}^{-1}$. Compost was provided two weeks before planting, and then one week after planting. Provision of NPK fertilizer was at a rate of $6 \mathrm{~g} \mathrm{pot}^{-1}$ or equivalent to $100 \mathrm{~kg} \mathrm{ha}^{-1}$

\section{Planting of grasses}

Planting materials consisted of three types of grass. Planting materials of $H$. acutigluma were in the form of tillers with the leaves were cut $15 \mathrm{~cm}$ long and roots were about $1 \mathrm{~cm}$, each pot was planted with five tillers. $P$. purpureum and $S$. spontaneum planting materials were in the form of $15 \mathrm{~cm}$ long cuttings with two buds, one cutting was planted in each pot. Then, the planting materials were planted in the media according to each type of treatment as previously determined.

\section{Plant maintenance}

The grasses were maintained for 135 days with scheduled watering. Weeding and pests and diseases control were carried out manually. After 135 days, the grasses were harvested to collect data on the grass shoot and root dry weight; the $\mathrm{Pb}$ metal concentration on the grass tissue; and the $\mathrm{Pb}$ concentration on the tailing media after the grass planting was completed. Harvested grasses were cleaned from the soil and the dirt attached to them was cleaned by using running water. Drying of biomass was done using an oven at $100^{\circ} \mathrm{C}$ for 24 hours, and after a constant weight was reached. The shoot and root dry weight were then measured.

\section{$\mathrm{Pb}$ metal extraction}

Sampling of plants was carried out by taking one complete grass plant with roots and shoot of each type of soil. The first process carried out after sampling was cleaning of the plant to ensure that there was no soil attached to the roots or leaves. Plants that have been separated by roots and leaves were then weighed. After 
that, each of the roots and leaves was chopped into small sizes, and was then re-weighed for roots, leaves, and soil. After that, the sample was dried using an oven at a temperature of $120^{\circ} \mathrm{C}$ for 2 hours. After ensuring that the samples were completely dry, then the samples were weighed and the dry weight was recorded. Some of the samples that had been treated were put into a beaker and provided with $\mathrm{HCl}$ and $\mathrm{HNO}_{3}$ in a ratio of 1: 3 as much as $10 \mathrm{~mL}\left(\mathrm{HCl}\right.$ and $\mathrm{HNO}_{3}$ were used to remove calcium and magnesium mineral crust that attaches to metals), then the samples were kept for 2 days. After 2 days, heating is done at $100^{\circ} \mathrm{C}$ is done using the oven, after the yellow vapor runs out the temperature is increased to $200^{\circ} \mathrm{C}$ The destruction is terminated when it is out white steam and liquid in the flask left around $0.5 \mathrm{~mL}$ (for one hour). Cool and dilute with $\mathrm{H}_{2} \mathrm{O}$ and the volume is adjusted to $50 \mathrm{~mL}$, shake until homogeneous, leave overnight or filtered with W-41 filter paper to obtain clear extract Extract is cooled then diluted with ion-free water to $25 \mathrm{~mL}$, then shaken until homogeneous, leave overnight. Clear extracts were used to measure heavy metals $\mathrm{Pb}, \mathrm{Cd}, \mathrm{Co}, \mathrm{Cr}, \mathrm{Ni}, \mathrm{As}, \mathrm{Sn}, \mathrm{Ag}, \mathrm{Se}$, Mo using Atomic Absorption Spectrophotometry (AAS) or SSA Flame method for ppm concentration level (Soil Research Institut 2009).

\section{Observation of variables}

Observation of $\mathrm{pH}, \mathrm{CEC}$ and $\mathrm{Pb}$ concentration of tailings media after planting were used as supporting data. The main observation data were shoot dry weight, root dry weight, shoot $\mathrm{Pb}$ content and root $\mathrm{Pb}$ content. The main observation data were subjected to ANOVA of factorial Completely Randomized Design to see the effect of treatment interactions between the type of grass and the type of amelioration on the observed variables. The supporting and main observed data were used to calculate the shoot absorption efficiency, root absorption efficiency, bioaccumulation factor (BCF), translocation factor (TF), and phytoremediation ability.

Efficiency of $\mathrm{Pb}$ absorption was calculated by the formula (Baker 1981):

$$
\text { Absorption Efficiency of } \mathrm{Pb}(\%)=\frac{\mathrm{Pb} \text { content in Dry weight of plants }(\mathrm{mg} / \mathrm{plant})}{\mathrm{Pb} \text { content in the soil }(\mathrm{mg} / \mathrm{kg})}
$$

The ability to accumulate $\mathrm{Pb}$ metal in the soil and translocate it to shoots was determined by the value of bioconcentration factor (BCF) and translocation factor (TF), calculated by the following formulas (Sharma et al. 2010; $\mathrm{Ng}$ et al. 2016):

$$
\begin{aligned}
& \text { Bioconcentration Factor }(\mathrm{BCF})=\frac{\mathrm{Pb} \text { root content }(\mathrm{mg} /}{\mathrm{kg}) \mathrm{Pb} \text { content in the soil }(\mathrm{mg} / \mathrm{kg})} \\
& \text { Translocation Factor }(\mathrm{TF})=\frac{\mathrm{Pb} \text { shoot content }(\mathrm{mg} /}{\mathrm{.kg}) \mathrm{Pb} \text { root content }(\mathrm{mg} / \mathrm{kg})}
\end{aligned}
$$

BCF values were used to assess the ability of grass to accumulate $\mathrm{Pb}$ metal from the media. The criteria used for $\mathrm{BCF}$ values are: if the $\mathrm{BCF}$ value is $>1$, then the grass is classified as an accumulator, and if the BCF value is $<1$, then the grass is classified as an excluder. Whereas, the ability of $\mathrm{Pb}$ metal translocation from root to shoot was determined by translocation factor value (TF). If the TF value is $>1$, the mechanism of $\mathrm{Pb}$ transfer by grass is classified as phytoextraction and if the TF value is $<1$, the mechanism of $\mathrm{Pb}$ translocation by grass is classified as a phytostabilization mechanism (Ng et al. 2016). The TF and $\mathrm{BCF}$ variables were used to assess the ability of grass to remediate $\mathrm{Pb}$, where phytoremediation is the difference between BCF and TF (Baker 1981).

\section{Data analysis}

Data on shoot dry weight, root dry weight, shoot $\mathrm{Pb}$ content, and root $\mathrm{Pb}$ content, were processed using ANOVA with factorial Completely Randomized Design to see the effect of interaction between types of grasses and types of amelioration on the observed variables. The difference between treatment means was determined by an LSD (Least Significance Different) test with a significance level of LSD $(\alpha=5 \%)$ and LSD $(\alpha=1 \%)$. Data Analysis was performed by using the assistance of EXCEL macros to perform basic statistical analysis on routine agricultural experiments, DSAASTAT Ver.1.021.

\section{RESULTS AND DISCUSSION}

\section{pH conditions and cation exchange capacity of tailings media}

The media was $100 \%$ sand with a texture of almost sandy. $\mathrm{pH}$ of $\mathrm{KCl}(1: 1)$ of 4.70 was classified as acidic, total $\mathrm{N}(\%)$ of $0.01, \mathrm{P}-\mathrm{Bray} \mathrm{I}(\mathrm{ppm})$ of $2.70, \mathrm{~K}-\mathrm{dd}(\mathrm{m} / 100$ g) of $0.06, \mathrm{Ca}(\mathrm{me} / 100 \mathrm{~g})$ of $0.30, \mathrm{Mg}(\mathrm{me} / 100 \mathrm{~g})$ of 0.13 , each was in very low criteria. Meanwhile, the initial $\mathrm{Pb}$ content was $27.6 \mathrm{ppm}$. After treatment, the final tailings $\mathrm{pH}$ of the study was still in highly acidic to acidic range. Increase of $\mathrm{pH}$ can occur with the addition of lime, but the addition of compost can cause a decrease in $\mathrm{pH}$, especially after planting of $P$. purpureum and $S$. spontaneum. Cation exchange capacity (CEC) was very low, addition of lime and compost ameliorants was able to increase the CEC value but it remained in very low category. CEC increase in compost ameliorant was higher than that of limestone ameliorant (Table 1).

\section{The effect of grass types and types of ameliorant treatments and their interactions on observed variables}

There was no significant interactions effect of types of grass by types of ameliorant on almost all observation variables, except for shoot dry weight and efficiency of shoot $\mathrm{Pb}$ uptake that was highly significantly affected. The effect of single factor treatment of grass species was highly significant on almost all the observed variables, but its effect on shoot $\mathrm{Pb}$ content and Phytoremediation was not significant. Meanwhile, the single factor types of ameliorant significantly affected shoot and root dry weight, efficiency of shoot and root $\mathrm{Pb}$ uptake but had no effect on both shoot $\mathrm{Pb}$ content and root $\mathrm{Pb}$ content, $\mathrm{BCF}, \mathrm{TF}$, and phytoremediation ability (Table 2). 
Table 1. $\mathrm{pH}$ and $\mathrm{CEC}$ at the end of planting of tailings media

\begin{tabular}{|c|c|c|c|c|c|}
\hline \multirow{2}{*}{ Variable } & \multirow{2}{*}{ Types of grass } & \multicolumn{4}{|c|}{ Types of ameliorant } \\
\hline & & Lime & Criteria* & Compost & Criteria* \\
\hline \multirow[t]{3}{*}{$\mathrm{pH}, \mathrm{KCl}(1: 1)$} & P. purpureum & 5.2 & Acidic & 3.70 & Highly acidic \\
\hline & S. spontaneum & 5.7 & Slightly acidic & 3.70 & Highly acidic \\
\hline & H. acutigluma & 5.1 & Acidic & 4.90 & Acidic \\
\hline \multirow{3}{*}{ Cation Exchange Capacity (CEC) (me/100 g) } & P. purpureum & 0.83 & Greatly low & 2.09 & Greatly low \\
\hline & S. spontaneum & 0.83 & Greatly low & 2.09 & Greatly low \\
\hline & H. acutigluma & 0.92 & Greatly low & 0.84 & Greatly low \\
\hline
\end{tabular}

Note: * Bogor soil research center (2005).

Table 2. The ANOVA results observed variables under the treatments of types of grass and types of ameliorant and their interactions

\begin{tabular}{|c|c|c|c|c|c|}
\hline Variable & Effect & Types of grass & Types of ameliorant & Interactions & C.V. $(\%)$ \\
\hline Shoot dry weight $(\mathrm{g})$ & $\begin{array}{l}\text { ProbF } \\
\text { Sign. }\end{array}$ & $\begin{array}{l}1.550 \mathrm{E}-08 \\
* *\end{array}$ & $\begin{array}{l}4.784 \mathrm{E}-03 \\
* *\end{array}$ & $\begin{array}{l}2.942 \mathrm{E}-04 \\
* *\end{array}$ & 16.22 \\
\hline Root dry weight (g) & $\begin{array}{l}\text { ProbF } \\
\text { Sign. }\end{array}$ & $\begin{array}{l}2.371 \mathrm{E}-06 \\
* *\end{array}$ & $\begin{array}{l}8.632 \mathrm{E}-03 \\
*\end{array}$ & $\begin{array}{l}2.234 \mathrm{E}-01 \\
\mathrm{~ns}\end{array}$ & 21.40 \\
\hline Shoot $\mathrm{Pb}$ content $(\mathrm{mg} / 100 \mathrm{~g})$ & $\begin{array}{l}\text { ProbF } \\
\text { Sign. }\end{array}$ & $\begin{array}{l}0.076540 \\
\text { ns }\end{array}$ & $\begin{array}{l}0.384932 \\
\text { ns }\end{array}$ & $\begin{array}{l}0.123218 \\
\text { ns }\end{array}$ & 11.51 \\
\hline Root $\mathrm{Pb}$ content $(\mathrm{mg} / 100)$ & $\begin{array}{l}\text { ProbF } \\
\text { Sign. }\end{array}$ & $\begin{array}{l}0.012132 \\
*\end{array}$ & $\begin{array}{l}0.108997 \\
\text { ns }\end{array}$ & $\begin{array}{l}0.449626 \\
\text { ns }\end{array}$ & 19.49 \\
\hline Shoot efficiency of $\mathrm{Pb}$ Absorption (\%) & $\begin{array}{l}\text { ProbF } \\
\text { Sign. }\end{array}$ & $\begin{array}{l}5.329 \mathrm{E}-05 \\
* *\end{array}$ & $\begin{array}{l}3.464 \mathrm{E}-03 \\
* *\end{array}$ & $\begin{array}{l}1.029 \mathrm{E}-02 \\
*\end{array}$ & 25.07 \\
\hline Root efficiency of $\mathrm{Pb}$ Absorption (\%) & $\begin{array}{l}\text { ProbF } \\
\text { Sign. }\end{array}$ & $\begin{array}{l}1.642 \mathrm{E}-05 \\
* *\end{array}$ & $\begin{array}{l}1.028 \mathrm{E}-02 \\
*\end{array}$ & $\begin{array}{l}4.833 \mathrm{E}-01 \\
\mathrm{~ns}\end{array}$ & 26.84 \\
\hline Bioacumulation concentration factor (BCF) & $\begin{array}{l}\text { ProbF } \\
\text { Sign. }\end{array}$ & $\begin{array}{l}0.043909 \\
*\end{array}$ & $\begin{array}{l}0.269687 \\
\text { ns }\end{array}$ & $\begin{array}{l}0.503637 \\
\mathrm{~ns}\end{array}$ & 26.30 \\
\hline Tranlocation Factor (TF) & $\begin{array}{l}\text { ProbF } \\
\text { Sign. }\end{array}$ & $\begin{array}{l}7.830 \mathrm{E}-08 \\
* *\end{array}$ & $\begin{array}{l}1.130 \mathrm{E}-01 \\
\text { ns }\end{array}$ & $\begin{array}{l}2.816 \mathrm{E}-01 \\
\mathrm{~ns}\end{array}$ & 21.80 \\
\hline Phytoremediation ability & $\begin{array}{l}\text { ProbF } \\
\text { Sign. }\end{array}$ & $\begin{array}{l}0.082174 \\
\text { ns }\end{array}$ & $\begin{array}{l}0.185472 \\
\text { ns }\end{array}$ & $\begin{array}{l}0.391632 \\
\text { ns }\end{array}$ & 27.22 \\
\hline
\end{tabular}

Note: $* *=$ highly significant $(\mathrm{p}<0.01)$ and $*$ significant $((\mathrm{p}<0.05), \mathrm{ns}=$ not significant. $\mathrm{CV}$ : coefficient of variation $(\%)$

Table 3. Means of shoot dry weight and efficiency of $\mathrm{Pb}$ absorption on shoots in the interaction between treatments of types of grass and types of ameliorant

\begin{tabular}{|c|c|c|}
\hline \multirow{2}{*}{ Grass species } & \multicolumn{2}{|c|}{ Types of ameliorant } \\
\hline & Lime & Compost \\
\hline \multicolumn{3}{|c|}{ Shoot dry weight (g plant ${ }^{-1}$ ) } \\
\hline P. purpureum & $276.0 \mathrm{~d}$ & $336.4 \mathrm{c}$ \\
\hline S. spontaneum & $454.9 \mathrm{~b}$ & $759.4 \mathrm{a}$ \\
\hline H. acutigluma & $108.3 \mathrm{f}$ & $137.8 \mathrm{e}$ \\
\hline $\operatorname{LSD}(\mathrm{p}=0.05) \mathrm{int}$ & 28.79 & \\
\hline \multicolumn{3}{|c|}{ Shoot efficiency of $\mathrm{Pb}$ absorption } \\
\hline P. purpureum & $7.4 \mathrm{c}$ & $10.0 \mathrm{~b}$ \\
\hline S. spontaneum & $11.6 \mathrm{~b}$ & $27.5 \mathrm{a}$ \\
\hline H. acutigluma & $3.9 \mathrm{~d}$ & $5.0 \mathrm{~d}$ \\
\hline $\operatorname{LSD}(p=0.05) \mathrm{int}$ & 1.96 & \\
\hline
\end{tabular}

Note: The numbers followed by different letters in each variable indicate a significant difference in LSD (Least Significance Different) with lowercase letters for the significance level of LSD $(\mathrm{p}=0.05)$

\section{Shoot dry weight and shoot efficiency of $\mathrm{Pb}$ absorption}

$H$. acutigluma has different shoot and root shapes than $P$. purpureum and $S$. spontaneum, but $P$. purpureum and $S$. spontaneum have similar form of shoot and roots. The ANOVA results showed a significant interaction effect between grass type as and types of ameliorant on shoot dry weight and efficiency of $\mathrm{Pb}$ abruption (Table 2). The results of LSD test $(\mathrm{p}=0.05)$. Table 3 showed that the highest dry weight of shoots was found in S. spontaneum which was planted in media equipped with compost, followed by the same grass planted in lime-fed media. This shows that $S$. spontaneum produces the highest dry weight of shoots regardless of the type of ameliorant provided in the growing media. This is because naturally, S. spontaneum growth is indeed better able to survive on critical land with high $\mathrm{Pb}$ exposure conditions (Mukharjee et al. 2017).

The efficiency of $\mathrm{Pb}$ absorption in $S$. spontaneum on media with compost ameliorant differed significantly from other treatments. In this condition, S. spontaneum has the highest efficiency of $\mathrm{Pb}$ absorption (Table 3 ). This can be caused by an increase in biomass which can also lead to increased efficiency of $\mathrm{Pb}$ absorption as stated by Ameen et al. (2018) that increase in efficiency of Pb uptake by plants will increase in line with the increase in biomass production. 


\section{Root dry weight, shoot and root $\mathrm{Pb}$ content, roots efficiency of $\mathrm{Pb}$ absorption and phytoremediation ability}

The interaction treatment between grass type and ameliorant type did not significantly affect root dry weight, shoot and root $\mathrm{Pb}$ content, roots efficiency of $\mathrm{Pb}$ absorption and phytoremediation ability (Table 2), but it is seen that the addition of compost tends to cause increase of root growth (Figure 1.A), decrease of shoot and root $\mathrm{Pb}$ content (Figure 1.B), increase of root efficiency of $\mathrm{Pb}$ absorption (Figure 1.C) and decrease of phytoremediation ability in $H$. acutigluma and $P$. purpureum and increase of phytoremediation ability in $S$. spontaneum (Figure 1.D).

The shoot $\mathrm{Pb}$ content of $S$. spontaneum exceeded that of $P$. purpureum and $H$. acutigluma; on the contrary, the root $\mathrm{Pb}$ content of the $H$. acutigluma was higher than that of the $S$. spontaneum and the P. purpureum. The high root $\mathrm{Pb}$ content of $H$. acutigluma causes the overall $\mathrm{Pb}$ network to be able to exceed the $S$. spontaneum and $P$. purpureum (Figure 2.A and 2.C). The root and shoot $\mathrm{Pb}$ contents of lime ameliorant treatment was higher than that of composted ameliorant treatment (Figure 2.B and 2.D).

Although shoot and root $\mathrm{Pb}$ contents under lime ameliorant treatment were higher than the compost treatment, but the ratio between shoot $\mathrm{Pb}$ content and root $\mathrm{Pb}$ in compost ameliorant (1.05) was higher than rootshoot $\mathrm{Pb}$ ratio in lime ameliorant (0.94). This indicates that lime has a higher ability to increase root $\mathrm{Pb}$ than compost, and conversely, compost has a higher ability to increase shoot $\mathrm{Pb}$ than lime ameliorant. The difference in $\mathrm{Pb}$ content between types of grass and type of plant organ can be caused by differences in root and shoot systems in the three types of grass used. S. spontaneum and P. purpureum rooting are relatively similar but $H$. acutigluma was found to have finer and denser roots than $P$. purpureum and $S$. spontaneum. According to Datta et al. (2017), metal accumulation can differ between plants, caused by differences in the root system. Fibrous roots can cause large surface absorption areas in the root system.

According to Ukhopadhyay and Aiti (2010), plants with high biomass and fast-growing tend to have better metal absorption and metal translocation. This can be seen in the highest efficiency of $\mathrm{Pb}$ absorption occurring (Figure 2.E and 2.F). The efficiency of $\mathrm{Pb}$ uptake in compost ameliorant was higher that the lime ameliorant. Addition of compost to sand-dominant soils such as tailings causes reduced washing of nutrients from the medium so that nutrients are more available (Sabeen et al. 2013). Addition of compost to three types of grass caused an increase in root dry weight and shoot dry weight. Furthermore, according to Sheoran et al. (2016) and Zhang et al. (2016), increase of growth can result in an increase in $\mathrm{Pb}$ accumulation. But in this study, the opposite situation did happen, where the compost treatment successfully increased the growth but not the $\mathrm{Pb}$ content in the shoots and roots. The results showed an increase in growth due to compost (Table 1) causing a decrease in shoot and root $\mathrm{Pb}$ contents (Figure 2.D).

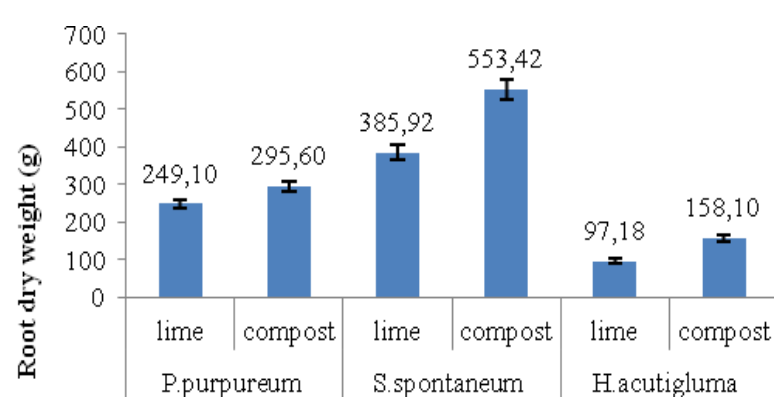

A
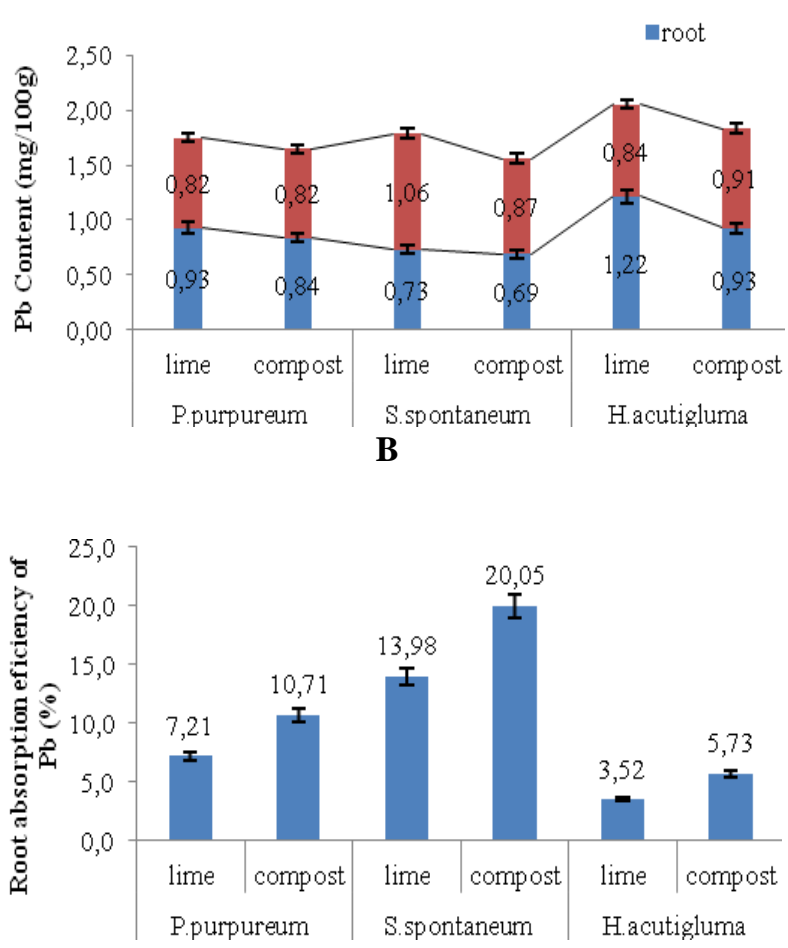

C

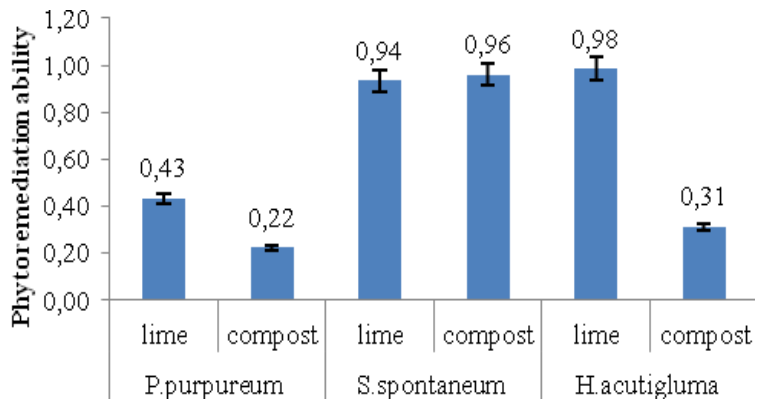

D

Figure 1. A. Root dry weight, B. Shoot and root $\mathrm{Pb}$ content, C. Roots efficiency of $\mathrm{Pb}$ absorption, $\mathrm{D}$. Phytoremediation ability on interactive treatment between the type of grass and the type of ameliorant 


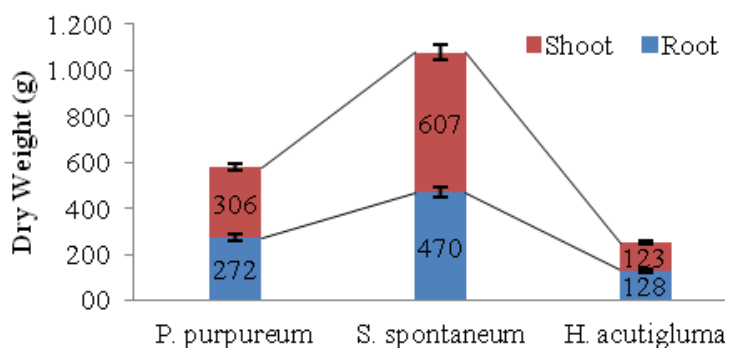

A

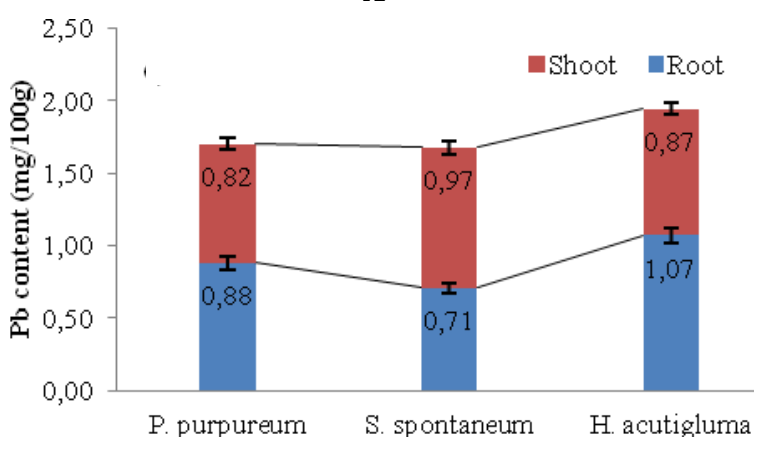

C

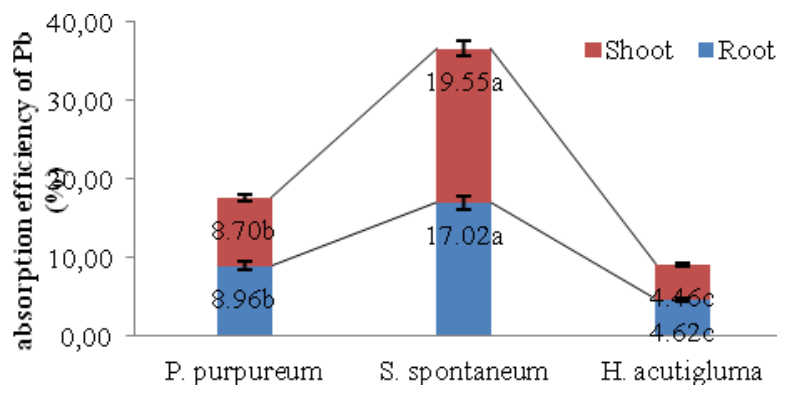

$\mathbf{E}$

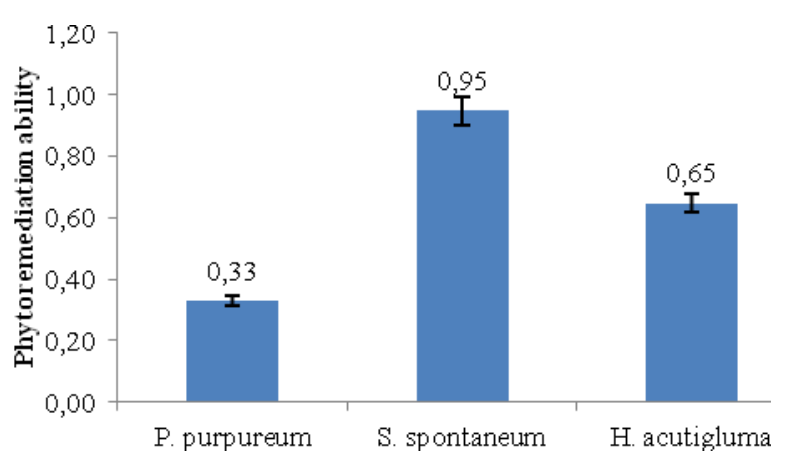

G

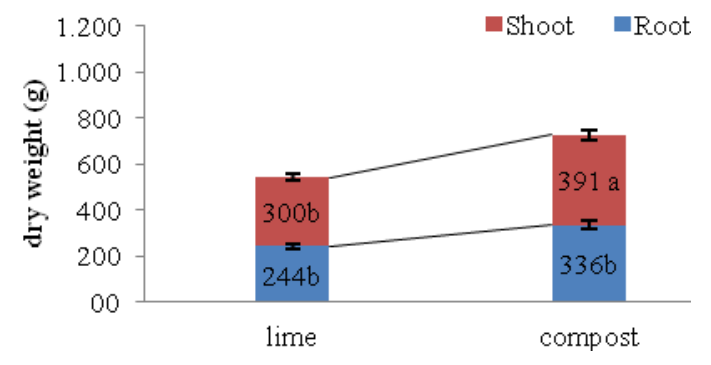

B

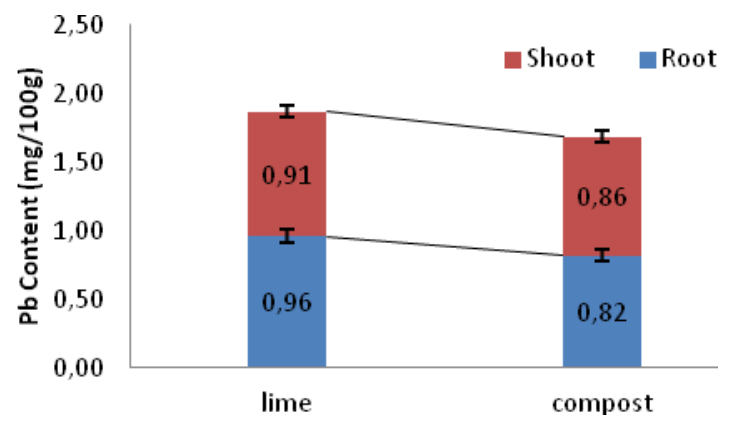

D

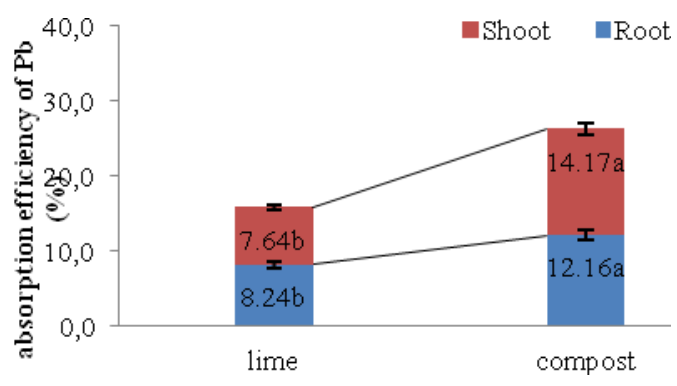

$\mathbf{F}$

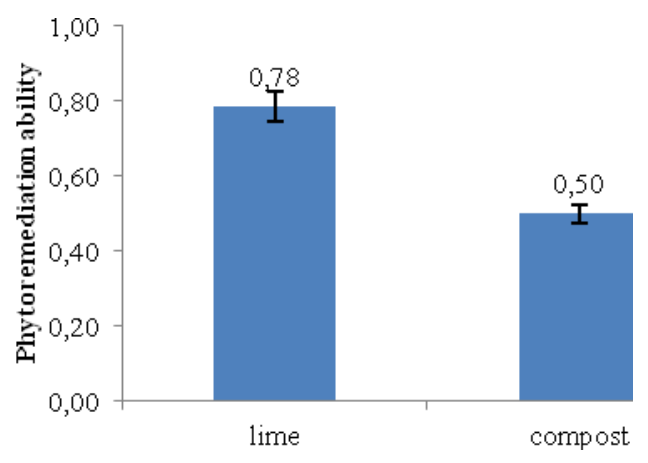

H

Figure 2. A. Shoot and root dry weight in the single factor treatment of grass type, B. Shoot and root dry weight in the single factor treatment of ameliorant type, $\mathrm{C}$. Content shoot and root $\mathrm{Pb}$ in the single factor treatment of grass type, $\mathrm{D}$. Shoot and root $\mathrm{Pb}$ content in the single factor treatment of ameliorant type, E. Shoot and root Efficiency of $\mathrm{Pb}$ absorption in the single factor treatment of grass type, $\mathrm{F}$. Shoot and root efficiency of $\mathrm{Pb}$ absorption in the single factor treatment of ameliorant type, G. Phytoremediation ability. Pb in the single factor treatment of grass type, H. Phytoremediation ability in the treatment of single factor type ameliorant. nOTE: The numbers followed by different letters in each variable indicate a significant difference in LSD (Least Significance Different) with lowercase letters for the significance level of LSD $(p=0.05)$ 
In the interaction treatment between grass type and ameliorant type, although it did not significantly affect the shoot $\mathrm{Pb}$ content and root $\mathrm{Pb}$ content, the interaction between grass type and ameliorant type significantly affected the efficiency of $\mathrm{Pb}$ uptake in shoots (Table 2). In $P$. purpureum and $H$. acutigluma, a decrease in shoot $\mathrm{Pb}$ content and root $\mathrm{Pb}$ content was followed by a decrease in phytoremediation values, despite an increase in absorption efficiency. In S. spontaneum, there is a slightly different tendency; there was a decrease in shoot $\mathrm{Pb}$ content and $\mathrm{Pb}$ root in $S$. spontaeum followed by increased phytoremediation ability (Figure 2.G and 2.H). This is thought to be due to the greater efficiency of $\mathrm{Pb}$ uptake in $S$. spontaneum as compared to the increase in absorption efficiency in $P$. purpureum and H. acutigluma (Figure 2.E).

\section{Bioconcentration factor (BCF) and Translocation Factor (TF).}

Table 4 shows that even though different types of ameliorants were provided, it did not cause changes in the criteria for grass species based on BCF and TF values.

BCF is a reflection of the ability of plants to hold root $\mathrm{Pb}$. Among these three grass species, $P$. purpureum and $H$. acutigluma have better ability to hold $\mathrm{Pb}$ rooted than $S$. spontaneum (Table 4; Figure 3.A). Accumulator plants are able to survive even though the concentration of contaminants in their body tissues is very high. These plants are able to remodel contaminants in their body tissues (Tangahu et al. 2011). Whereas, metal excluder is a type of plant that performs basic strategy by preventing metals from entering the shoots by limiting the metal to remain rooted; this can be done by changing the membrane permeability or changing the cell wall capacity to binding or releasing metal chelating compounds so that the metal concentration around its roots remains low and constant (Cunningham et al. 1995).

Translocate factor (TF) values indicated that all three types of grass have phytostabilization properties (Table 4; Figure 3.B and 3.D). Phytostabilization is a process of immobilizing contaminants in the root area by certain compounds released by plants. Plants can stabilize $\mathrm{Pb}$ in the soil, making them harmless (Lamria and Patricus 2015). BCF increases with lime addition compared to composting (Figure 3.A and 3.C.). This shows an improvement in $\mathrm{pH}$ causing more roots to hold $\mathrm{Pb}$ compared to compost ameliorant. Tailings media that use ameliorants to increase $\mathrm{pH}$ (lime) can increase tolerance to heavy metals; this occurs in Triticale, Helianthus annuus and Brassica juncea grown on soil contaminated with heavy metals (Chirakkara et al. 2016).

The ability of phytoremediation is reflected by the ability to hold metal at the root (BCF) reduced by the ability of metal translocation to shoot (TF). Based on this, the ability of BCF is important. This is in line with $\mathrm{Xu}$ et al. (2017) who stated that roots have a more important role than shoots in remediating $\mathrm{Pb}$-contaminated soils. TF values also influence the ability of phytoremediation. A high TF value will reduce the value of phytoremediation. Besides being determined by BCF and TF values, the role of absorption efficiency and absorption capacity is also worth taking into account (Chirakkara et al. 2016).

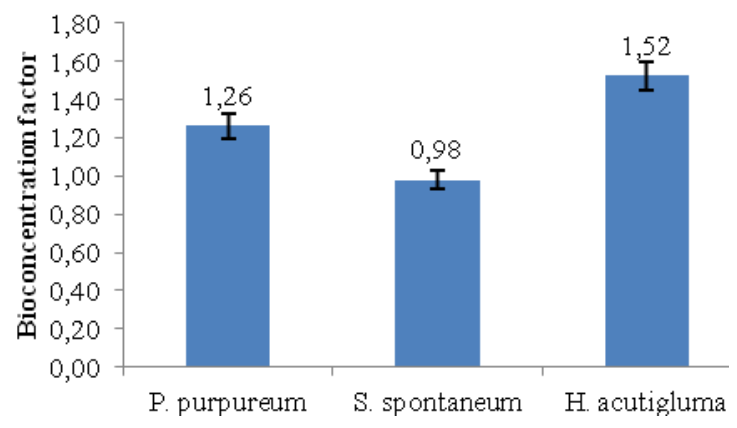

A

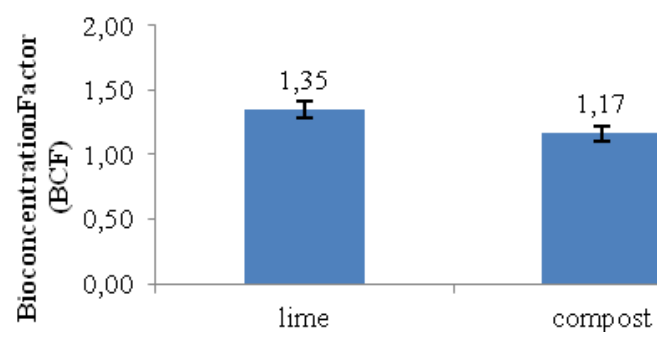

C

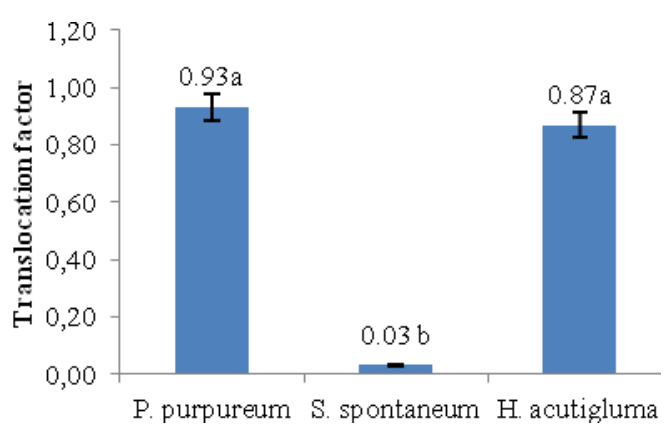

B

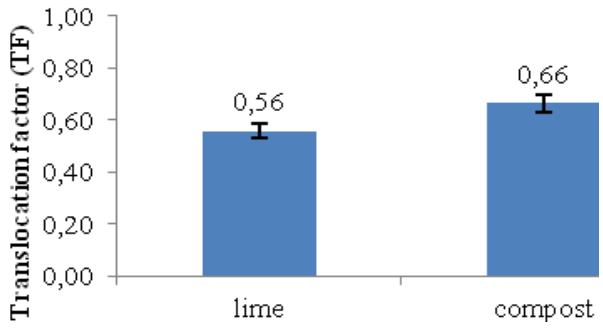

D

Figure 3. A. Bioconcentration factor $(\mathrm{BCF})$ on various types of grass, B. Translocation factor (TF) on various types of grass, C. Bioconcentration factor (BCF) in various types of ameliorant, D. Translocation factor (TF in various types of ameliorant. Note: The numbers followed by different letters in each variable indicate a significant difference in LSD (Least Significance Different) with lowercase letters for the significance level of LSD $(p=0.05)$ 
Table 4. Grasses criteria based on the value of Bioconcentration Factor (BCF) and Translocation Factor (TF)

\begin{tabular}{|c|c|c|c|c|c|}
\hline \multirow{2}{*}{ Variable } & \multirow{2}{*}{ Types of grass } & \multicolumn{4}{|c|}{ Types of ameliorant } \\
\hline & & Lime & Criteria & Compost & Criteria \\
\hline \multirow{3}{*}{ Bioconcentration factor (BCF) } & P. purpureum & 1.32 & Accumulator & 1.20 & Accumulator \\
\hline & S. spontaneum & 0.97 & Exluder & 0.98 & Exluder \\
\hline & H. acutigluma & 1.74 & Accumulator & 1.31 & Accumulator \\
\hline \multirow[t]{3}{*}{ Translocation factor (TF) } & P. purpureum & 0.89 & Phytostabilisation & 0.98 & Phytostabilisation \\
\hline & S. spontaneum & 0.04 & Phytostabilisation & 0.02 & phytostabilisation \\
\hline & H. acutigluma & 0.75 & Phytostabilisation & 0.99 & Phytostabilisation \\
\hline
\end{tabular}

The lowest translocation value of 0.03 was found in $S$. Spontaneum. This indicates that $S$. spontaneum translocation ability was the lowest. Even though the $S$. spontaneum BCF value was lower but the TF $S$. spontaneum value is also low, the resulting phytoremediation value remains high (Figure 1.E). Increased growth due to compost promotes increased $\mathrm{Pb}$ translocation capacity in tissues (Figure 2.D). Increased nutrient in grass can increase metal $\mathrm{Pb}$ translocation factors from soil to root and from root to shoot (Arunothai et al. 2014; Ameen et al. 2018; Chuan et al.(2016).

This is thought to be related to increased nutrient uptake efficiency in S. spontaneum, $P$. purpureum and $H$. acutigluma (Figures 2.B and 2.D). In addition, this also occurs as a result of roots developing better, so that growth also gets better overall (Figure 2.A and 2.G). Then there will be an increase in the efficiency of $\mathrm{Pb}$ absorption. This was found in $S$. spontaneum, which had the highest absorption efficiency compared to $H$. acutigluma and $P$. purpureum (Figure 2.C and 2.E).

This was suspected even though the BCF values of $P$. purpureum and $H$. acutigluma were high and were accumulators, but these two types of grass also had high TF values. This affects the value of phytoremediation. Reducing BCF values with high $\mathrm{TF}$ values causes a decrease in phytoremediation values. In S. Spontaneum, a low BCF value was offset by a TF value that was also low, so that the obtained phytoremediation value still exceeded the value of phytoremediation in $P$. purpureum and $S$. spontaneum (Figure 2.G and 2.H).

TF values can affect the value of phytoremediation, in this study the lowest TF values were found in $S$. spontaneum compared to $P$. purpureum and $H$. acutigluma (Figure 3.C). In addition to TF values, the factor that needs to be taken into account is the efficiency of $\mathrm{Pb}$ absorption, Efficiency of $\mathrm{Pb}$ absorption by grass. S. spontaneum was the highest compared to $P$. purpureum and species (Figures 2.G and 2.H), which would have a positive effect on the strength of phytoremediation.

Although lime causes grass to have a higher efficiency of $\mathrm{Pb}$ absorption compared to compost, the ability of phytoremediation of lime remains higher than compost. This is because the addition of compost causes better growth, so that it can increase the efficiency of $\mathrm{Pb}$ absorption, but the increased efficiency of $\mathrm{Pb}$ absorption due to composting has not been able to improve the ability of phytoremediation.

The application of compost to $P$. purpureum, $S$. spontaneum and $H$. acutigluma can lead to increased growth and efficiency of absorption of $\mathrm{Pb}$ in shoots and roots. this is because compost used is able to improve the chemical and microbiological properties of tailings and leads to increased growth and crop yield (Magnano et al. 2018). But the increase in growth due to composting was not followed by an increase in the concentration of root and shoot $\mathrm{Pb}$. The concentration of $\mathrm{Pb}$ shoot and $\mathrm{Pb}$ root due to the administration of lime is higher than that of compost. So that the ability of phytoremediation is seen to be higher by giving lime than by compost. Grass that is given lime is seen to increase the concentration of $\mathrm{Pb}$ on the shoots and roots. It is suspected that grass with the addition of lime has a lower growth than if given compost, so that $\mathrm{Pb}$ concentration of heavy unity will be higher and affect the concentration of $\mathrm{Pb}$ in the weight of the plant.

In these three types of grass the growth of grass with high biomass will cause an increase in the efficiency of $\mathrm{Pb}$ absorption in the shoots and roots. The efficiency of $\mathrm{Pb}$ uptake from $S$. spontaneum was better than $P$. purpureum and $H$. acutigluma. This ability also contributes to the ability of phytoremediation. Although the ability of $S$. spontaneum's BCF ability was lower compared to $P$. purpureum and $H$. acutigluma, but $S$. spontaneum had a low $\mathrm{TF}$ value so that ultimately the phytoremediation ability of $S$. spontaneum remained higher than $H$. acutigluma and $P$. purpureum.

In addition to lime, the value of phytoremediation is higher than the addition of compost, while growth and efficiency of $\mathrm{Pb}$ absorption increase with the addition of compost. This is because the lime media has high BCF values and low TF values. So that it will cause a higher phytoremediation value. In this condition, the plant will retain more $\mathrm{Pb}$ in the roots and less $\mathrm{Pb}$ is translocated to the shoot.

Adding compost causes better grass growth (Magnano et al. 2018). It was also found in $P$. purpureum, $S$. spontaneum and $H$. acutigluma has grown in tailings media. Increasing growth in the type of grass will cause increased efficiency of $\mathrm{Pb}$ absorption in shoots and roots. However, the concentration of shoots of $\mathrm{Pb}$ and $\mathrm{Pb}$ root due to providing lime remained higher than compost. 
According to Ashraf et al. (2011) plant metabolisms can influence the process of increasing $\mathrm{Pb}$, so that at a better growth rate with improved $\mathrm{Pb}$ concentrations it is not necessarily able to increase shoot and root $\mathrm{Pb}$ concentrations because there are other factors such as plant metabolism which can also affect the ability of $\mathrm{Pb}$ absorption by roots and the translation is in the header.

The mechanism of phytoremediation that plants can do is phytoextraction and phytostabilization (Nascimento et al. 2014). Based on TF values <1, S. Spontaneum, $P$. purpureum, and $H$. acutigluma were assessed as phytostabilization. Where plants with high bioconcentration factors (BCF) and low translocation factors $(\mathrm{TF})$ have the potential for phytostabilization (Yoon et al 2006).

The lowest TF value was found in $S$. spontaneum compared to $P$. purpureum and $H$. acutigluma. In addition to TF values, the factors that need to be improved are absorption efficiency, absorption efficiency by grass. $S$. spontaneum was the highest compared to $P$. purpureum and $H$. acutigluma, which had a positive effect on the strength of phytoremediation.

In this type of grass, the growth of grass with high biomass will increase the efficiency of $\mathrm{Pb}$ absorption in shoots and roots. The efficiency of $\mathrm{Pb}$ absorption by $S$. spontaneum also supports phytoremediation capabilities. The criteria used to select plants for phytoremediation such as short life cycles, wide distribution, large shoot biomass (Mazumdar and Das 2015), are also owned by $S$. Spontaneum. S. Spontaneum has a resistance to growing environments which are limited to nutrients and water, grows faster, high heavy metals, wider distribution, and larger biomass than $P$. purpureum and $H$. acutigluma.

\section{ACKNOWLEDGEMENTS}

The authors would like to thank the Ministry of Research, Technology, and Higher Education for the funding support for the research. The research fund was part of the funding scheme of Hibah Penelitian Disertasi Doktor (PDD), year 2018. Moreover, the authors would also like to acknowledge the Biotrop Laboratory in Bogor, as well as all other parties that had contributed to this research.

\section{REFERENCES}

Ameen A, Chaochen T, Han LGHX. 2018. Short-term response of switchgrass to nitrogen, phosphorus, and potassium on semiarid sandy wasteland managed for biofuel feedstock. Bioenerg Res 11: 228-238.

Antwi EK, Danquah BJ, Asabere SB, Takeuchi K, Wiegleb G. 2014. Land cover transformation in two post-mining landscapes subjected to different ages of reclamation since dumping of spoils. Springer Open J 3: 1-23

Aparecida D, Rafaela B, Figueiredo R. 2014. Canonical correlations in $P$. purpureum grass for energy purposes. African J Biotechnol 13: 36663671.

Arunothai J, Hans B, Suwasa K. 2014. Effects of inorganic nitrogen form on growth, morphology, $\mathrm{N}$ uptake, and nutrient allocation in hybrid napier grass (Pennisetum americanum $\mathrm{Cv}$. Pakchong1 ). Ecol Eng 73: 653-658.

Ashraf MA, Maah MJ, Yusoff I. 2011. Heavy metals accumulation in plants growing in ex-tin mining catchment. Intl J Environ Sci Tech 8: 401-416

Badan Standardisasi Nasional 1999. Standar Nasional Indonesia Batas maksimum cemaran logam berat dalam pangan. ICS 67.220.20 SNI 7387, Indonesia. [Indonesian]

Baker AJM, Brooks RR. 1989. Terrestrial higher plants which hyperaccumulate metallic elements - A review of their distribution ecology, and phytochemistry. Biorecovery J 1 (2): 81-126.

Balai Penelitian Tanah 2009. Petunjuk Teknis analisa kima tanah, tanaman, air dan pupuk. Balai Penelitian Tanah. Bogor, Indonesia. [Indonesian]

Chirakkara RA, Cameselle C, Reddy KR. 2016. Assessing the applicability of phytoremediation of soils with mixed organic and heavy metal contaminants. Rev Environ Sci Biotechnol 15: 299-326

Chuan C, Amru N, Boyce N, Rahman M. 2016. Effects of different soil amendments on mixed heavy metals contamination in vetiver grass. Bull Environ Contam Toxicol 97: 695-70.

Cunningham SD, Berti WR, Huang JW. 1995.

Phytoremediation of contaminated soils. Trends Biotechnol 13: 393-397.

Datta U, Mitra A, Zaman S, Pramanick P, Pal N. 2016. Bioaccumulation of heavy metals by thermal power station. Intl J Innov Res Sci Eng Technol 5: 1457-1462.

Datta U, Zaman S, Mitra A. 2017. Enrichment factor and translocation factor of selected heavy metals in Saccharum spontaneum and Typha $P$. purpureum ina species growing in the fly ash ponds of mejia thermal power station (Mtps). J Sci Eng Health Manag 1: 35-40.

Ferry Y, Towaha J, Sasmita KD. 2010. Perbaikan lahan bekas tambang timah: studi kasus; uji media tanah bekas tambang dengan beberapa macam kompos untuk budidaya lada. Buletin Riset Tanaman Rempah dan Aneka Tanaman Industri 1: 296-308. [Indonesian]

Gerjardt KE, Gerwing PD, Greenberg BM. 2016. Opinion: Taking phytoremediation from proven technology to accepted practice. Plant Sci 256: 170-185.

Gosh M, Singh SP. 2005. Comparative intake and phytoextraction study of soil induced chromium by accumulation a high biomass weed species. Appl Ecol Environ Res 3 (2): 67-79.

Grice AC, Clarkson JR, Calvert M. 2011. Geographic differentiation of management objectives for invasive species: a case study of Hymenachne amplexicaulis in Australia. Environ Sci Pollut Res 4: 986-997.

Khan MMN, Islam E, Irem S, Akhtar K, Ashraf MY. 2018. Pb-induced phytotoxicity in para grass (Brachiaria mutica) and castor bean (Ricinus communis L.): antioxidant and ultrastructural studies. Chemosphere 200: 257-265.

Kooner R, Mahajan BVC, Dhillon WS. 2014. Heavy metal contamination in vegetables, fruits, soil and water - a critical review. Intl J Agric Environ Biotechnol 7: 603-612

Magnano AL, Nann AS, Krug P, Astrada E, Vicari R, Quintana RD. 2018. Effects of livestock exclusion on density, survival and biomass of the perennial sagebrush grass Hymenachne pernambucense (Poaceae) from a temperate fluvial wetland. Acta Oecologica 86: 72-78.

Mazumdar K and Das S. 2015. Phytoremediation of $\mathrm{Pb}, \mathrm{Zn}, \mathrm{Fe}$, and $\mathrm{Mg}$ with 25 wetland plant species from a paper mill contaminated site in North East India. Environ Sci Pollut Res 22: 701-710

Meeinkuirt W, Kruatrachue M, Tanhan P, Chaiyarat R, Pokethitiyook P. 2013. Phytostabilization potential of $\mathrm{Pb}$ mine tailings by two grass species, Thysanolaena maxima and Vetiveria zizanioides. Water Air Soil Pollut 224: 1-12.

Mukherjee P, Roychowdhury R, Roy M. 2017. Phytoremediation potential of rhizobacterial isolates from kans grass (Saccharum spontaneum) of fly ash ponds. Clean Technol Environ Pol 19 (5): 1373-1385

Narendra BH. 2016. Adaptability of some legume trees on quartz tailings of a former tin mining area In Bangka Island, Indonesia. J Degraded Mining Lands Manag 4: 152-43.

Nascimento EB, Silva RF, Alleoni PH, Grazziotti FG, Fonseca, Nardis BO. 2014. Availability and accumulation of lead for forage grasses in contaminated soil. J Soil Sci Plant Nutr 14: 783-802.

Ng CC, Rahman M, Boyce AN, Abas MR. 2016. Heavy metals phyto-assessment in commonly grown vegetables: Water spinach ( $I$. aquatica) and okra (A. esculentus ). Springerplus 5: 1-9. 
Nidaa N, Chaudhry AS, Shaheen S, Ullah K, Khan F. 2017. Ethnobotanical studies of fodder grass resources for ruminan animals, based on the traditional knowledge of indigenous communities in Central Punjab Pakistan. J Ethnobiol Ethnomed 13: 1 16.

Nurcholis M, Wijayani A, Widodo A. 2013. Clay and organic matter applications on the coarse quartzy tailing material and the sorghum growth on the post tin mining at Bangka Island. J Degraded Mining Lands Manag 1: 27-32.

Oktavia D, Setiadi Y, Hilwan I. 2015. The comparison of soil properties in heath forest and post-tin mined land: basic for ecosystem restoration. Procedia Environmental Sciences 28: 124-131.

Pandey VC, Prem P, Omesh B, Akhilesh K, Nandita S. 2015. Phytodiversity on fly ash deposits : evaluation of naturally colonized species for sustainable phytorestoration. Environ Sci Pollut Res Intl 22: $2776-2787$

Paz-Alberto AM, Sigua GC. 2012. Phytoremediation : a green technology to remove environmental pollutants. Amer J Climate Ch 2013: 71-86.

Pinho S, Ladeiro B. 2012. Phytotoxicity by lead as heavy metal focus on oxidative stress. J Bot 2012: 1-10.

Ranjan V, Sen P, Kumar D, Sarsawa A. 2015. A review on dump slope stabilization by revegetation with reference to indigenous plant. Ecol Process 4: 1-12.

Sabeen M, Mahmood Q, Irshad M, Fareed I, Khan A, Ullah F, Tabassum S. 2013. Cadmium phytoremediation by Arundo donax L. from contaminated soil and water. Biomed Res Intl 2013: 324-330

Saletnik B, Zaguła B, Bajcar M, Puchalski C. 2016. Accumulation of cadmium, lead and mercury in seedlings of selected sugar beet varieties as a result of simulated soil contamination J.Microbiol Biotech Food Sci 5: 351-355.

Sari E. 2015. Eksplorasi vegetasi fitoremediator dan bakteri rizosfer resisten logam berat $\mathrm{Pb}$ dan $\mathrm{Sn}$ di lahan bekas tambang timah Pulau Bangka. [Tesis]. Institut Pertanian Bogor, Bogor. [Indonesian]
Sarwar N, Imran M, Shaheen MR, Ishaque W, Kamran MA, Matloob A, Rehim A, Hussain S. 2017. Phytoremediation strategies for soils contaminated with heavy metals: Modification and future perspectives. Chemosphere 171: 710-721.

Sharma S, Sharma P, Mehrota. 2010. Bioaccumulation of heavy metals in Pisum sativum L. growing in fly ash amended soil. J Amer Sci 6: 4350.

Sheoran V, Singhsheoran, PoonampooniaA, 2016. Factors affecting phytoextraction: A review. Pedosphere 26: 148-166.

Sidauruk L, Sipayung P. 2015. Phytoremediation of contaminated land at Medan industrial area by ornamental plants. Jurnal Pertanian Tropik 22: 178-186. [Indonesian]

Ukhopadhyay M, Aiti SM. 2010. Phytoremediation of metal mine waste. Appl Ecol Environ Res 8: 207-222.

Xavier, Shereen S, Olson, Dawn M, Coffin, Alisa W, Strickland TC 2017. Perennial grass and native wildflowers: A synergistic approach to habitat management. Insects 8: 1-13.

Xu J, Cai Q, Wang H, Liu X, Lv J. 2017. Study of the potential of barnyard grass for the remediation of $\mathrm{cd}$ - and $\mathrm{Pb}$-contaminated soil. Environ Monit Assess 189: 1-16.

Yang Y, Nan Z, Zhao Z. 2014. Bioaccumulation and translocation of cadmium in wheat (Triticum aestivum L .) and maize (Zea mays L .) from the polluted oasis soil of Northwestern China. Chem Spec Bioavailabil 26: 43-51.

Yoon J, Cao X, Zhou Q, Ma QL 2006. Accumulation of Pb, Cu, and Zn in native plants growing on a contaminated Florida site. Sci Total Environ 368: 435-956.

Zhang X, Xuehong Z, Huang K. 2016. Phytostabilization of acidic soils with heavy metal contamination using three forage grasses in combination with organic and inorganic amendments. Soil Sediment Contam 25: 459-475. 